\title{
The College: an analysis of members' views ${ }^{\dagger}$
}

\author{
R. E. Kendell and R. Duffett
}

\begin{abstract}
Aims and method In November 1997 a questionnaire was sent to a large random sample of members, fellows, affiliates and inceptors living in the UK or the Republic of Ireland.

Results One thousand four hundred and seventy-six completed questionnaires were available for analysis, a response rate of $63 \%$. The College was complemented for raising standards of education and training in psychiatry and criticised for not trying hard enough, or failing, to influence the policles of the Department of Health. A high proportion of respondents highly valued the British Journal of Psychiatry and Psychiatric Bulletin but few made use of the library. A high percentage of Irish. Welsh and Scottish members, and of members of the five smaller faculties, participated in and expressed their appreciation of the activities of the College. Implications Whatever its other failings the College is not dominated by general psychiatrists and their interests, or by London-based psychiatrists. It is surprisingly successful at involving Scottish, Welsh and Irish psychiatrists, and members of the smaller faculties, in its activities. To some extent, however, the faculties are thriving at the expense of the English divisions.
\end{abstract}

Early in 1997 the honorary officers decided to send a questionnaire to a large random sample of members in order to find out - for the first time and with a guarantee of anonymity - what the membership at large thought of the College and its various activities. A four-page questionnaire was composed and piloted in the autumn of that year on a sample of 200 members and fellows. A revised version was then posted in November 1997 to 2337 members, fellows, inceptors and affiliates with a home address in the UK or the Republic of Ireland and who were not registered as retired. These 2337 constituted a random $50 \%$ sample of fellows, a $25 \%$ sample of members, a $50 \%$ sample of inceptors and all affiliates. Non-responders were sent a further letter and questionnaire in January 1998.

The composition of the total sample and the response rate obtained are shown in Table 1 . The comparatively low overall response rate $(63 \%)$. and the much lower response rate from members

'See editorial pp.1-2, this issue. than from fellows (52 v. 85\%) was the result of an unfortunate mishap in which the completed questionnaires of 312 members were lost by a research assistant in the College Research Unit before being coded. Although these 312 members were sent a further questionnaire, accompanied by a suitably apologetic letter, only a minority returned this replacement questionnaire. Moreover, because all questionnaires were anonymous, it was not possible to tell how many of the 144 returns received from members after the despatch of these replacement questionnaires were replacements sent back by these 312 rather than delayed responses to the original mailing. The true overall response rate (i.e. the response rate if these questionnaires had not been lost) would therefore have been between 70 and $77 \%$ and the true response rate from members between 65 and $77 \%$.

All ratings were analysed in three different ways: according to the respondent's College status (fellow, member, affiliate or inceptor), according to the setting of their main psychiatric practice (general psychiatry, child psychiatry, old age, learning disability, psychotherapy, forensic, substance misuse or undecided) and according to the country in which they worked (England, Scotland, Wales, Northern Ireland or the Republic of Ireland).

The first question asked respondents to rank each of the College's 10 main publications and activities on a three-point scale (highly valued, sometimes valued and very little value) (full details of the questionnaire are avallable from the authors upon request). Overall, the highest ratings were obtained by the British Journal of Psychiatry and Psychiatric Bulletin ('highly valued' by 59 and $54 \%$ respectively) and the lowest ratings by Library services (rated very little value by $93 \%$ ). This is not a criticism of the library staff. It is an almost inevitable consequence of the severe restrictions imposed by the limited room available to the College library and the wealth of alternative resources now available to most psychiatrists.

Overall, the College's Annual and Winter meetings were only rated as 'highly valued' by $11 \%$, compared with $12 \%$ for local divisional meetings 
Table 1. Composition of the sample and response rates

\begin{tabular}{lccl}
\hline & Number in sample & Analysable retums & Response rate \\
\hline Fellows & 500 & 424 & $85 \%$ \\
Members & 1250 & 645 & $52 \%$ \\
Affiliates & 187 & 95 & $51 \%$ \\
Inceptors & 400 & 312 & $78 \%$ \\
Total & 2337 & 1476 & $63 \%$ \\
\hline
\end{tabular}

and $27 \%$ for faculty or speciality section meetings. However, there were major differences in the perceived value of these three different types of meeting by speciality and division. Faculty or speciality section meetings were 'highly valued' by a high proportion, ranging from 46 to $56 \%$, of all six kinds of specialist psychiatrists but only by $16 \%$ of general adult psychiatrists. Similarly. local division meetings were appreciated more by Scottish, Welsh or Irish psychiatrists (highly valued by $22-30 \%$ ) than by English psychiatrists (highly valued by only $9 \%$ ).

Across all 10 activities listed in question 1 the highest levels of appreciation were expressed by Irish psychiatrists, particularly those from the Republic, and by learning disability and old age psychiatrists.

There was a series of questions about personal participation in College activities. Overall, $30 \%$ of respondents had visited the College building in Belgrave Square within the last 12 months, and for fellows the figure was $51 \%$. On the other hand, $38 \%$ had never entered the College in their lives. Overall, $47 \%$ had attended a College conference (sectional, divisional or national) within the previous 12 months, $13 \%$ were currently sitting on a College committee or working group (including divisional and faculty executive committees) and a further $19 \%$ had previously done so. As before, all these percentages were considerably higher for fellows. As these percentages do not include a wide range of other College roles, like acting as an MRCPsych examiner, as an assessor for the British Journal of Psychiatry or as a College representative on appointment committees, they suggest that a high proportion of all members and fellows participate personally in College affairs. Although, for understandable reasons, the proportion of Scottish and Irish psychiatrists who had never entered the College building in Belgrave Square was comparatively high (50$58 \%$ ) their participation rates in College activities were just as high as those of English psychiatrists. Similarly, the percentages currently or previously sitting on a College committee or working group were just as high for specialists as for general adult psychiatrists. Indeed, for psychotherapists and forensic and substance misuse psychiatrists they were higher.

Respondents were asked whether they considered they obtained value for money for their annual subscription and their replies are summarised in Table 2. Overall, $16 \%$ answered 'definitely yes' and another $36 \%$ yes probably'. Only $13 \%$ said 'definitely not'. The highest proportions of 'definitely or probably yes' ratings were provided by the inceptors (whose subscription is relatively low). by psychiatrists working in the Republic of Ireland or Wales, and by substance misuse specialists. The lowest proportions of definitely or probably yes responses were provided by affiliates, by members, by child and adolescent psychiatrists and by psychotherapists. Respondents were also asked how well they thought the College served the interests of its members and fellows compared with the other medical Royal Colleges. Not surprisingly $42 \%$ said they could not judge, but of those who did express a view more rated the College better as opposed to worse than the other colleges (16 v. $10 \%)$. Those working in Wales and Ireland (both Northern Ireland and the Republic) and in learning disability were particularly likely to rate us higher than the other colleges.

The majority view of the College's public education activities, such as the recent Defeat Depression campaign, was either that they were 'important' (43\%) or that they were 'important but achieving very little' (40\%). Similar views were expressed about the activities of the College Research Unit, though here a higher proportion (34\%) admitted to having no clear view. Only $2 \%$ of respondents said of either public education or research that it should not be part of the College's activities. The questionnaire also asked what proportion of the College's subscription income should be available for research or public education activities and offered a choice of five options ranging from $0 \%$ to ' $8 \%$ or more'. Overall the responses to these questions indicated that the College membership would be happy to see $4 \%$ of their subscriptions spent on public education and at least $4 \%$ spent on research.

The questionnaire ended with four open-ended questions and $92 \%$ of respondents answered at 
Table 2. Responses to the question 'Do you consider that you get value for money for your subscription? Percentages replying 'definitely' or 'probably'

\begin{tabular}{|c|c|c|c|c|c|}
\hline \multicolumn{2}{|c|}{ College status } & \multicolumn{2}{|l|}{ Place of work } & \multicolumn{2}{|l|}{ Psychiatric speciallity } \\
\hline $\begin{array}{l}\text { Fellows } \\
\text { Members } \\
\text { Affiliates } \\
\text { Inceptors } \\
\text { (Overall }\end{array}$ & $\begin{array}{l}58 \% \\
42 \% \\
39 \% \\
66 \% \\
51 \%)\end{array}$ & $\begin{array}{l}\text { England } \\
\text { Scotland } \\
\text { Wales } \\
\text { Republic of Ireland } \\
\text { Northern Ireland }\end{array}$ & $\begin{array}{l}49 \% \\
46 \% \\
63 \% \\
72 \% \\
45 \%\end{array}$ & $\begin{array}{l}\text { General adult } \\
\text { Child \& adolescent } \\
\text { Old age } \\
\text { Learning disabillty } \\
\text { Psychotherapy } \\
\text { Forensic } \\
\text { Substances misuse }\end{array}$ & $\begin{array}{l}50 \% \\
41 \% \\
45 \% \\
46 \% \\
42 \% \\
53 \% \\
69 \%\end{array}$ \\
\hline
\end{tabular}

least one of these. The four questions and the most frequent replies to them are shown in Table 3.

\section{Discussion}

Although the main focus of interest is bound to be on the replies and comments of all 1476 respondents it is important to recognise that these were not a representative sample of the College's 9600 members, or even of those living in the British Isles and not yet retired. Over a third of the questionnaires sent out were either not returned or not available for analysis and it cannot be assumed that non-responders hold the same views as responders. In addition. fellows, inceptors and affliates were all deliberately over-represented in the original sample in order to ensure that adequate numbers of replies were obtained from these three important minorities. Members were correspondingly under-represented, and their comparative under-representation was accentuated by the loss of $\mathbf{3 1 2}$ of their completed questionnaires. It would have been possible to allow for these distortions by appropriate weighting of the

Table 3. The most frequent replies to the four open-ended questions

What do you consider the College's most important achievement since its foundation in 1971?

Raising standards of education and training (426)

Raising the status of psychiatry as a medical speciality (131)

Providing a focus and support for all psychiatrists (70)

Producing the British Journal of Psychiatry and other publications (57)

Raising the public profile and improving the image of psychiatry (43)

What do you consider the College's most important weakness or failing to be?

Not trying hard enough, or failing, to influence the policies of the Department of Health (310)

Failing to represent the views of the 'silent majority' of psychiatrists (193)

Failing to transmit important information to members (132)

Failing to improve standards of training (123)

Failing to address issues of recruitment and retention within the profession (99)

Being too heavily focused on London (82)

Bureaucratic and administrative failings (75)

Failure to raise or monitor standards of service provision (63)

Failure to integrate the different branches of psychiatry (40)

What is the most important thing the College is not doing at present which it ought to do, or try to do? Define publicly the role of psychiatrists (178)

Provide better support for psychiatrists (137)

Campaign to reduce the stigma of mental illness (121)

Involve its members more effectively (94)

Review the membership examination (87)

Streamline meetings or hold fewer of them (73)

Develop better relationships with other bodies or professions (59)

Reduce its expenditure (49)

If the College were to close down any of its current activities which should it be? Nothing should be closed down (91)

The College Research Unit (64)

Library services (49) 
scores of the four categories of membership, as in an epidemiological survey based on weighted samples, but it seemed simpler to present the raw percentages and totals, leaving readers to make the necessary adjustments. It is important to bear in mind, for example, that the proportion of all respondents who have never been in the College building in Belgrave Square $(38 \%)$ or never sat on a College committee or working party $(68 \%)$, will be simultaneously inflated by the disproportionate numbers of affiliates and inceptors in the total sample, and diminished by the disproportionate number of fellows and by their high response rate.

People often refer loosely to 'the College', and in doing so sometimes confuse the three separate meanings of this term - the College's total membership of over 9600 fellows, members, inceptors and affiliates and their many corporate activities; an elegant building in Belgrave Square; and the main decision-making committees that meet in that building (the Council and its Executive and Finance Sub-Committee and the Court of Electors). 'The College' is sometimes criticised for being too heavily focused on or preoccupied with London, and indeed 82 of the respondents to this questionnaire $(5.6 \%)$ expressed this criticism. It is also criticised at times for being dominated by general psychiatrists and their interests. Perhaps the most important single conclusion to be drawn from this survey is that these criticisms are largely unwarranted and that several of the College's most important and dynamic activities are far removed both from London and from general psychiatry. The best attended and most highly valued College meetings are those organised by the Scottish, Welsh and Irish divisions, and by the child and adolescent, old age, learning disability, psychotherapy and forensic faculties. Indeed, between 57 and $69 \%$ of the members of these five faculties had attended a College conference within the past 12 months, and in most cases this was a faculty meeting. Nor is participation limited to attending scientific meetings. Overall, $32 \%$ of respondents were currently or had previously been a member of a College committee or working group. Few would have predicted that this figure would be exceeded by respondents living in Wales (39\%) or Scotland $(36 \%)$ and by members of the substance misuse $(45 \%)$, forensic $(43 \%)$, psychotherapy $(35 \%)$, learning disability (33\%) and child and adolescent $(33 \%)$ faculties.

These participation levels were matched by the more subjective ratings. The highest valuable to me' scores across the 10 main College activities listed in question 1 were generated by psychiatrists working in the Republic of Ireland or Northern Ireland and by members of the learning disability and old age faculties. Even more striking, the highest proportions saying that they 'definitely' or 'probably' got value for money from their annual subscription were psychiatrists working in the Republic of Ireland or Wales, substance misuse specialists and inceptors. (It probably needs to be borne in mind in interpreting these figures that not all Irish psychiatrists maintain their membership of the College, that inceptors pay a much reduced annual subscription and that, by chance, a relatively high proportion of Welsh respondents were fellows.)

Although the results of this survey suggest that, on the whole, the College is succeeding in meeting the needs of its members and fellows, and in involving many of them in its activities, they also contain some important warnings and clear messages that changes are needed in some areas. The most important of these is the very low percentage of respondents who make any use of the College library. Even though many members of the staff of the College and its Research Unit, and several retired members and fellows living in London, use the library regularly it is clear that its role needs rethinking. By the time this paper is published Dr Pullen, the Librarian, will have put proposals to Council for the disposal of obsolete or little used books and journals and for focusing the activities of the library on electronic retrieval, literature searches and governmental and other contemporary publications.

The view expressed by over 300 respondents that the College's most conspicuous weakness has been its failure to influence government policies is obviously another important message. The College officers will need to think hard about tactics here because governments are not usually easy to influence and the best tactics change over time and may vary from one minister to the next. At the time of writing we can be fairly certain that ministers and senior officials in the Department of Health are in no doubt about the College's views, or about the changes we would like to see in the mental health policies they inherited from the previous administration; and by the time this paper is published we should know how successful we have been in influencing their policies, particularly for "care in the community'.

A third important message is the alarmingly high proportion of respondents, particularly of child and adolescent psychiatrists, who regard the College's Annual and Winter meetings as of little value. It is clearly vital that the College's main annual meeting should be valued for both social and scientific reasons, and attract the same high proportion of members that, for example, the annual meeting of the American Psychiatric Association succeeds in doing. Council has already decided not to hold any more Winter meetings and to concentrate on making a success of the Annual Meeting at which new 
fellows and honorary fellows are formally welcomed and new presidents installed. Success or failure will clearly hinge on persuading the six smaller faculties that this is their conference too, and not just for general psychiatrists and College politicians.

Finally, it is reassuring to learn that a high proportion of members and fellows regard the work of the Research Unit and the College's public education activities as important and worthwhile, and that they are happy to see $4 \%$ or so of their annual subscriptions devoted to each of these activities. In fact, the formal aims of the College commit us to "promote study and research work in psychiatry and related subjects" and to "improve public knowledge of psychiatry and the work of psychiatrists". At a time when there is clearly going to be increasing emphasis on the efficacy and cost-effectiveness of all clinical services, and when the public are increasingly knowledgeable about the strengths and weaknesses of the National Health Service and increasingly critical of doctors, the need for well organised research and effective public education requires no emphasis. There will be important opportunities in both fields if we are sufficiently astute to recognise and exploit them.

\section{Acknowledgements}

We are grateful to the many members of the College who completed and returned this questionnaire, and to Catherine Ayres for her assistance with the analysis of their responses.

*R. E. Kendell, President, Royal College of Psychiatrists, 17 Belgrave Square, London SW1X 8PG; and Richard Duffett, Research Worker, College Research Unit, London

*Correspondence

\title{
The supervision register: 19 months after its introduction
}

\author{
Charles Hindler
}

\begin{abstract}
Aims and method To examine whether, 19 months after its introduction, the goals of the supervision register have been met. A matched case-control study of patients on the supervision register and Care Programme Approach was conducted.

Results Cases and controls demonstrated similar socio-demographic characteristics, primary diagnoses and community psychiatric care. The supervision register group were more likely to use concurrent alcohol and/or illicit drugs ( $P=0.001)$ or suffer with an accompanying personality disorder $(P=0.0001)$, and were less likely to have experience of a long-term relationship $(P=0.003)$. Nineteen months after registration, the supervision register group were more likely to be violent to others $(P=0.002)$ or involved in serious threatening behaviour to others $(P=0.0007)$. Relapse of mental illness was the only significant predictor of future violence in the supervision register group $(P<0.01)$.
\end{abstract}

Clinical implications Patients with a history of violence to others were found to be appropriately placed on the supervision register but continued to demonstrate aggressive behaviour after registration, indicating that the goal of the supervision register to prioritise most appropriate care and treatment for this group of patients has not been met.

Supervision registers are an integral part of the Care Programme Approach (Department of Health, 1990) and represent a mechanism to identify those patients most at risk of harming themselves or others, who should then be given the highest priority for care and treatment and thereby protect this vulnerable group of patients and the wider public (Bottomley, 1994). Three mental health trusts in south-east London agreed with their purchaser that the Care Programme Approach and supervision register 